\title{
Judicial Passivism at the European Court of Justice?
}

\author{
ERNŐ VÁRNAY*
}

\begin{abstract}
According to the generally accepted understanding, judicial activism arises when a court behaves improperly, straying beyond the limits of the judicial function and acting like a legislature.

It is convincing that in the great majority of the cases the Court of Justice of the European Union fulfils the roles assigned to it by the founding treaties of the European Union without any excess, but there are decisions which may be characterized as activist, be they necessary or useful for the proper functioning of the European legal system, and there are decisions (refusing or avoiding to decide) which may be qualified as manifestations of judicial passivism.

Judicial passivism is defined in the narrow sense of the term, i.e., when the court clearly refuses or avoids to decide the case before it, or does not answer the question legitimately referred to it. In the jurisprudence of the CJEU, such cases arise when the Court systematically waits for the withdrawal of the action, exceeds the reasonable time of the proceedings, or does not answer the question raised in the preliminary ruling procedure by the national court. The inadmissibility of questions referred by national courts may be perceived as passivism when the qualification of 'not a court or tribunal' in the sense of Article 267 TFEU is questionable, or when the scope of the EU Charter of Fundamental Rights is defined too narrowly. Cases may arise - at least in theory in which the Court, while it would be in a position to act, defers the question to the EU or the Member State's legislator or to the national judge to decide, with the not entirely convincing qualification of the act under scrutiny in annulment proceedings as 'not an act for the Article 263 TFEU'. The label 'judicial passivism in a broad sense of the term' is used when the Court sticks to its position in a questionable manner (conservatism as passivism), steps back from its earlier position, narrowing the scope of EU law expressly or implicitly overruling its former decision, or it introduces new conditions with the same result (retreat).

It has been demonstrated that the Court systematically opposed the Member States, the Commission and the parties in the main proceedings, arguing in favour of inadmissibility of referrals for preliminary questions - the Court avoided, in a large number of cases, the temptation of judicial passivism. On the other hand, the Court's increased rigour in the preliminary ruling procedures is detectable in recent years. The Court took a less benevolent approach towards the qualification of the referring body as 'court or tribunal'; the questions proved to be 'hypothetical' more often than before, and more importantly, the lack of sufficient information regarding the factual and regulatory context led more easily to inadmissibility.

The driving forces behind the passivism of the Courts of the European Union are the 'reasonableness' of the judiciary in a time of crisis of the European integration, self-defence against the overburden of case-law and against unnecessary pressure from the public, in order to maintain the health of the management of justice and a certain 'path-dependence' as far as the traditional theoretical foundations of European integration are concerned. Keywords: European Cour of Justice, passivism, deference, preliminary reference procedure, conservatism
\end{abstract}

\section{INTRODUCTION}

The activism of the European Court of Justice (ECJ) is a common place of political science and legal studies, very often with negative connotations. ${ }^{1}$ Convay stated that 'At the core of criticism of judicial activism lies a concern that the judiciary is acting outside its proper

* Research Chair, Hungarian Academy of Sciences, Centre for Social Sciences, Institute for Legal Studies Budapest, varnay.erno@tk.mta.hu.

1 The classic of classics is Hjaltje Rasmussen's book: Rasmussen (1986) The issue still seems topical: See Dawson, De Witte and Muir (2013). 
role'. Antony Arnull's definition is essentially the same 'It is a court that has behaved improperly by staying beyond the limits of the judicial function, by misusing its power.' ${ }^{2}$ Some complain that the activist judiciary is 'acting like a legislature' instead of a court'. In terms of judicial reasoning, activism refers to creative or innovative interpretations. ${ }^{3}$ The literature and the members of the Court themselves, qualified those decisions as activist judgments which introduced new legal institutions or legal principles into EU law and/or fulfilled lacunae in the Treaties clarifying uncertain legal terms. The driving forces behind this creativity were the effet utile of the Community (Union) law (construction of a genuine legal order); the will to contribute to the constitutionalization of the Community's legal regime (especially the protection of fundamental rights) ${ }^{4}$ and the building and maintaining of the common (internal) market. ${ }^{5}$

Critics often argue that the Court follows its own pro-integrationist agenda. The main tool used in order to attain these goals was the teleological method of interpretation.

The criticism against the activism of the European Court of Justice has not been limited to legal and political scholarship. Politicians and political movements have also expressed their dissatisfaction with the Court's activism. Maybe the most repeated statement was the 'manifesto' of Roman Herzog and Lüder Gerkens: Stop the European Court of Justice! ${ }^{6}$ More recently in the campaign before the 26 June 2016 UK referendum about leaving the EU, the Eurosceptic press and politicians presented the Court as consistently activist. $^{7}$

Against this background, it seems interesting to shed some light on the other, somewhat neglected, side of the spectrum, the passivism of the European Court of Justice.

The article is structured as follows. The next section tries to give a first definition of the notion of judicial passivism at the Court of Justice in its narrow and its broader senses. The subsequent section (2) explores different phenomena of judicial passivism in its narrow sense. In section 3 the different forms of passivism in its large sense are presented. The categories of the passivist approach are exemplified with the case law of the Court. Finally we conclude by arguing that besides the activist Court we have also a court with clearly identifiable passivist features. The driving forces behind the passivism of the Courts of the European Union are the 'reasonabless' of the judiciary in time of crisis of the European integration, self-defence against the overburden of the case-law and the unnecessary pressure from the public in order to maintain the health of the management of justice and a certain 'path-dependence' as far as the traditional theoretical foundations of European integration are concerned.

2 Arnull (2013) 215 For Takis Tridimas, activism is also related to the judicial function, and it arises when the court exceeds its limits. He argues, however, that there is 'No persuasive argument has been made, however, that in its case law the Court has exceeded its powers.' Tridimas (1996) 210.

3 Convay (2012) 18.

4 Weiler (1991) 2413-19.

5 'Le droit a été créateur et demeure conservatoire de l'unité de marché.' Lecourt (1976) 304, Maduro (1998).

${ }^{6}$ Herzog and Gerken (2008).

7 Editorial (2017) 311. On the 1995 'Euro-rebels' manifesto demanding among others 'the end to the Court of Justcice's activism', see Kostakopoulou (2017) 345. 


\section{PASSIVISM - REVERSED ACTIVISM?}

At the first sight, passivism has to be the opposite of activism. Judicial passivism is to be defined relative to the judicial function, i.e., to the proper role of the judiciary. Thielbörger does this in relation to the European Court of Human Rights. To him, judicial passivism is the opposite of judicial activism: 'It involves judges and courts that undergo what is required by their mandate. They leave decisions to the executive or legislature that should be decided by the judiciary, or they simply refuse to deliver a substantive decision at all., 8

One of the first publications on judicial passivism at the European Court of Justice was by Iris Goldner Lang and she suggests the term judicial passivism can be used in its narrow and large sense. '(The) definition of judicial passivism would apply to cases where the CJEU is consciously (actively) not using its powers where it should, and thereby sending a message to EU institutions, its Member States and other political actors in the EU.' ${ }^{9}$

Her examples are the well-known EU-Turkey Statement cases ${ }^{10}$ in which the General Court declined to determine the cases on merit, considering that the contested measure is not an act in the sense of Article 263 TFEU, consequently it has no jurisdiction. The cases may serve as an example of judicial passivism in its narrow meaning, only if the GC consciously and wrongly decided.

"... "judicial passivism in the extensive sense" would also encompass situations where the Court is using its judicial (e.g. interpretative) role, but it does so in a manner which deviates from the teleological interpretation to which the Court has accustomed us over the past decades of its adjudication.' 11

For Goldner Lang, the decisive factor is the 'consciousness' of the Court in deciding not to decide or to decide in a 'strict, formalistic way' and consciousness is equated with activism, she inevitably arrives at the conclusion that judicial passivism is a sub-category of judicial activism.

Whilst the author shares roughly the above definition of judicial passivism in its narrow sense, it is not considered that the phenomenon that describes qualifies as 'activism'. The judicial activism of the European Court of Justice always encompasses a quasi lawmaking activity in order to promote a 'European law friendly' development (introduction of new principles, enlarging the scope of the primary and/or secondary law) in the EU legal system. It is submitted that the judicial passivism of the Court of Justice in its narrow term includes different groups of cases in which the Court does not use its jurisdiction where it should or could. This is the case when the Court remains inactive and also when it deliberately chooses the alternative the consequence of which is non-decision.

8 Thielbörger (2012) 341. This definition is equivalent of the French term déni de justice: le refus par une juridiction de juger une affaire, alors qu'elle est habilitée à le faire. Par extension, le déni de justice peut être caractérisé par le retard excessif mis par des juges à statuer. https:// fr.wikipedia.org/wiki/D\%C3\%A9ni_de_justice, La Loi n²007-1787 du 20 décembre 2007 sur la simplification du Droit a caractérisé le déni de Justice par la circonstance que les juges ont refusé de répondre aux requêtes ou ont négligé de juger les affaires en état et en tour d'être jugées. https://www. dictionnaire-juridique.com/definition/deni-de-justice.php.

9 Goldner Lang (2018) 76.

10 T-192/16, NF v European Council (ECLI:EU:T:2017:128). The case on appeal before the Court of Justice C-208/17 P), T-193/16, NG v European Council (ECLI:EU:T:217:129), T-257/16, T-257/16, NM v European Council (ECLI:EU:T:2017:130).

11 Goldner Lang (2018) 76. 
It will be shown that the judicial passivism in its narrow sense exists in the practice of the CJEU, with Goldner Lang's example is definitely not an isolated case. The area of judicial passivism will be reconsidered in its large sense. Non-teleological interpretation may indeed be a manifestation of a passivist attitude, but in our understanding - as will be explained in section 3 - this type of judicial attitude contains rather decisions constituting a certain kind of conservatism and retreat from the earlier position taken by the Court narrowing the scope of the EU law.

\section{JUDICIAL PASSIVISM IN ITS NARROW SENSE IN THE JURISPRUDENCE OF THE COURT OF JUSTICE OF THE EUROPEAN UNION}

\subsection{Playing with time and procedural rules}

Maybe the most evident manifestation of judicial passivism is when the Court of Justice remains inert despite being asked to make a decision. This kind of situation arose concerning the new type of infringement procedure against Member States introduced by the Lisbon Treaty. When a Member State fails notify the European Commission of the implementation of a directive adopted in the ordinary legislative procedure, the Commission may ask the Court in the framework of the Article 258 Treaty on the functioning of the European Union (TFEU) to impose a financial sanction on the Member State in question. The first judgement was delivered on $8^{\text {th }}$ July 2019 - more than eleven years after entering into force of the new (3) paragraph of Article 260 TFEU. ${ }^{12}$ In the meantime, the European Commission brought more than twenty actions brought before the Court. Waiting systematically until the Commission withdraws the action, the Court left a number of questions unanswered e.g., how the Court decides on the scope of the procedure in terms of what constitutes a failure to notify? Does it cover only the 'not notifying anything' or does it cover also, as the Commission understands it, the partial transposition? Is the Court ready to accept the Commission's policy on types of financial sanctions, i.e., restricting to the penalty payment or does it wish to use its own full discretion as it did in Article 260 (2) TFEU procedures and to impose both of the two types? One the other hand, it has to be admitted that the effectiveness of the new procedure seems to be satisfactory as in most of the cases the Member State in question fully complied with the directive some months after the case had been brought to the Court. ${ }^{13}$

\subsection{Excess of the reasonable time for adjudication}

Another case of evident passivism is presented by the excess of the reasonable time for adjudication.

There are no time limits in the rules of procedures of the European Court of Justice. The length of the procedure before the European Court of Justice had long been an object of criticism in legal writings. Regarding the specificities of the working methods of the Court, especially the obligations emerging from a multilingual environment and the role of the Advocates General at the Court, the average duration of proceedings (in 2018, 16 months for the references for a preliminary ruling, 18.8 months for direct actions ${ }^{14}$ ) is respectable.

12 C-543/17, Commission v Belgium (ECLI:EU:C:2019:573).

13 Várnay (2017).

14 European Court of Justice (2018) 140. 
Procedures whose length exceeds the average are generally the competition (state aid) cases. ${ }^{15}$ It is no surprise that the reasonable length of the proceedings became an issue in such cases.

The Court first faced the question of the (un)reasonableness of the time of the proceedings before the lower EU court, namely the Court of First Instance - renamed as General Court in Baustahlgewebe. ${ }^{16}$ The Court implicitly accepted that the fundamental right that everyone is entitled to a fair and public hearing within a reasonable time by an independent and impartial tribunal established by law enshrined in Article 6 (1) of the ECHR is part of Community law. In that case, the Court laid down the reasonableness test 'such a period must be appraised in the light of the circumstances specific to each case and, in particular, the importance of the case for the person concerned, its complexity and the conduct of the applicant and of the competent authorities. ${ }^{\prime 7}$

In this case, 31 months and 11 days elapsed between the end of the written procedure and the decision to open the oral procedure, and in addition, 22 months elapsed between the close of the oral procedure and the delivery of the judgment of the Court of First Instance. ${ }^{18}$ The Court took into consideration the constraints inherent in proceedings before the Community judicature, especially the use of languages, the relative complexity of the case and concluded that the proceedings before the Court of First Instance did not satisfy the requirements concerning completion within a reasonable time. ${ }^{19}$ The Court 'for reasons of economy of procedure and in order to ensure an immediate and effective remedy regarding a procedural irregularity of that kind ${ }^{20}$ decided to annul the judgment of the Court of First Instance and imposed a fine of $2950000 \mathrm{ECU}$, instead of 3 million, to be paid by the appellant.

In Der Grüne Punkt, the Court referred to Article 6(1) ECHR as general principle which constitutes a right and this right was reaffirmed in Article 47 of the Charter of the European Union. ${ }^{21}$ The judgment was a starting point of a new case-law on sanctioning the excessive duration of the proceedings. The remedy for this irregularity is not to set aside the decision in question but it can give rise to a claim for damages brought against the Community (the Union). ${ }^{22}$

15 In 2017 the General Court delivered 6 judgments in competition cases after more than 3 years of proceedings. In 2018 (until the end of October) the General Court delivered 5 judgments after four years (48-49 months) of proceedings: T-419/14, Goldman Sachs Group v Commission (ECLI: EU:T:2018:445), T-441/14, BruggKabel and Kabelwerke v Commission (ECLI:EU:T:2018:453), T-449/14, Nexans France and Nexans v Commission (ECLI:EU:T:2018:456), T-475/14, Prysmian and Prysmiancavi e sistemi v Commission (ECLI:EU:T:2018:448), T-574/14, EAEPC v Commission (ECLI:EU:T:2018:605).

16 C-185/95, Baustahlgewebe GmbH v Commission (ECLI:EU:C:1998:608).

17 idem para 29.

18 idem paras 11 and 45 .

19 paras. $46-47$.

20 para 48.

21 C-385/07 P Der Grüne Punkt - Duales System Deutschland v. Commission (ECLI:EU: C:2009:456), paras. 178-79.

22 Idem paras. 195-96, Picod suggests that this represents a kind of retreat of the Court's previous case-law. Picod, Van Drooghenbroeck and Rizcallah (2018) 1003. From our perspective, this is a manifestation of judicial retreat - passivism in the broader meaning of the term. (See under Section 3.) 
More recently, in Gascogne, ${ }^{23}$ initiated by an action for damages caused by the excessive duration of the proceedings before the General Court, the General Court followed the Court's assessment in Gascogne Sack $^{24}$ and declared that in the light of the circumstances of Cases T72/06 and T79/06, the fact that 46 months elapsed between the end of the written part of the procedure and the opening of the oral part of the procedure shows that there was a period of unjustified inactivity (emphasis added - EV) of 20 months in each of those cases. ${ }^{25}$ Consequently, the General Court found that the procedure infringed the second paragraph of Article 47 of the Charter of Fundamental Rights of the European Union in that it exceeded the reasonable time for adjudicating, which constitutes a sufficiently serious breach of a rule of EU law intended to confer rights on individuals, which is one of the conditions of the Union's non-contractual liability for damages. ${ }^{26}$

\subsection{No answer to the referred question}

Another type of passivism may arise in the preliminary ruling procedure. In the framework of these proceedings, the Court is asked by the national court to give an answer on the interpretation of a primary or secondary law provision, the scope of a principle, or a fundamental right. The Court might also be asked about the validity of the acts act of EU bodies. The answer serves two different objectives: it allows the national court to decide on the EU-law related case following the authoritative interpretation given by the CJEU and it clarifies the authentic meaning (legality) of the particular provision or principle for the entire legal community.

Refusing, with no or unsatisfactory justification, to answer the question(s) of the referring national court is, in our understanding, a clear case of judicial passivism.

The Court does not have jurisdiction to answer a question referred by a body if it does not fulfils the necessary criteria to be regarded as a national court or tribunal for the purposes of Article 267 TFEU. ${ }^{27}$

The Court may refuse to rule on a question referred for a preliminary ruling by a national court where it is quite obvious that the interpretation of EU law that is sought bears no relation to the actual facts of the main action or its purpose, the facts of the case do not come under the scope of EU law, where the problem is hypothetical, or where the Court does not have before it the factual or legal material necessary to give a useful answer to the questions submitted to it. ${ }^{28}$ It must be added that in case of uncertainty of the admissibility of the request for a preliminary ruling the questions relating to EU law enjoy a presumption of relevance. ${ }^{29}$

23 T-577/14, Gascogne Sack Deutschland GmbH and Gascogne v European Union (ECLI: EU:T:2017:1) para. 76.

24 C-40/12 P, Gascogne Sack Deutschland v. Commission (ECLI:EU:C:2013:768) para. 102.

25 T-72/06, Groupe Gascogne v Commission (ECLI:EU:T:2011:671), T-79/06, Sachsa Verpackung v Commission (ECLI:EU:T:2011:674).

26 T-577/14, Gascogne Sack Deutschland and Gascogne v European Union (ECLI:EU:T:2017:1) paras. 76-78 The judgment had been appealed by the European Union - represented by the European Court of Justice - before the Court of Justice (C-138/17 P) but the appeal does not contend this part of the General Court's decision, which means that the Court of Justice implicitly accepts the unjustified inactivity of the General Court.

27 C-546/16, Montte (ECLI:EU:C:2018) par. 20.

28 C-62/14, Gauweiler and Others (ECLI:EU:C:2015:400) par. 25.

29 C-643/16, American Express (ECLI:EU:C:2018:67) par. 18. 
'The Court can pass a completely silent judgment refusing to give an answer on the grounds of lack of jurisdiction or inadmissibility, or considering that a reply is not necessary in the light of an answer already given to other queries raised by the national court. ${ }^{30}$

Interviews with Dutch judges revealed that in some cases the Court did not answered the referred question considering that 'the question is not relevant' in the case at hand. ${ }^{31}$

According to Wahl and Prete, the rather benevolent approach to issues under Article 267 TFEU has been transformed into a certain rigour, especially in the last few years. This is true both with respect to the checks on the conditions of jurisdiction and the fulfilment of the requirements of the newly enacted Article 94 of the Rules of procedure; '(U)nclear, incomplete or inconsistent references are regularly rejected as inadmissible. ${ }^{32}$

\subsubsection{The referring court is not a court or tribunal of a Member State within the meaning of Article 267 TFEU}

Whether the body referring the question to the Court is a court or tribunal within the meaning of Article 267 TFEU is a rarely asked question. If a body is not considered a court or tribunal under national law, the Court uses Vaassen criteria ${ }^{33}$ to confer that capacity with a view to the application of the articles of the Treaties relating to the preliminary ruling procedure. The Court is generally very 'generous' when considering the term 'court or tribunal'. ${ }^{34}$ Recently in Medisanus ${ }^{35}$ and Montte ${ }^{36}$ the Court examined ex officio if the referring bodies (the State Public Procurement Tribunal Slovenia and the Administrative Board of Contract Appeals of the Autonomous Community of the Basque Country, respectively) are to be classified as courts or tribunals for the purposes of Article 267 TFEU. The Court found that they fulfil all the necessary criteria to be regarded as a national court or tribunal for the purposes of Article 267 TFEU, and the questions referred to the Court are admissible. Recently, the Court has declared the request for a preliminary ruling from the Tribunal de Contas (Court of Auditors) as manifestly inadmissible, because it could not be established that in the case in the main proceedings it is performing a judicial function. ${ }^{37}$ This case was not a 'hard case' for the Court, given that the referring body could

${ }^{30}$ In cases like Vajnai, Centro Europa 7, Grogan or Mayr, in which the CJEU was directly asked about important points of constitutional principles that were either set aside or eluded, the unwillingness of the Court to engage with the issues raised was evident. Sarmiento (2012) 21.

31 Krommendijk (2019) 401.

32 Wahl and Prete (2018) 545.

33 A 'court or tribunal' under Art. 267 of the TFEU is (1) a body (2) which is established by law, (3) permanent and independent and (4) charged with the settlement of disputes defined in general terms (5) which is bound by rules governing inter partes proceedings similar to those used by ordinary courts of law, (6) in so far as it acts as the 'proper judicial body' for the disputes in question, which means that parties must be required to apply to the court or tribunal for the settlement of their dispute and its determination must be binding, and (7) is bound to apply rules of law.

34 Advocate General Ruiz Jarabo Colomer stated it in De Coster: 'The case-law is casuistic, very elastic and not very scientific, with such vague outlines that a question referred for a preliminary ruling by Sancho Panza as governor of the island of Barataria would be accepted.' C-17/00, De Coster (ECLI:EU:C:2001:366) para.14, See also Lenaerts, Maselis and Gutman (2014) 52-62.

35 C-296/15, Medisanus (ECLI:EU:C:2017:431) paras. 32-38.

36 C-546/16, Montte (ECLI:EU:C:2018:493) paras. 20-25.

37 Order of the Court of 25 April 2018 in case C-102/17, Secretaria Regional de Saúde dos Açores (ECLI:EU:C:2018:294). 
not clearly establish that it has the status of a third party in relation to the authority which adopted the contested decision, nor could it clearly establish whether the decision to be taken by it in the prior review proceedings as to the legality and the budgetary justification in question in the main proceedings will be taken by that body in a judicial capacity and not purely in an administrative capacity. ${ }^{38}$

A well-known counter example of the generally generous attitude of the Court is Belov. ${ }^{39}$ The Bulgarian Government and the European Commission considered that the referring body (Komisia za zashtitaot diskriminatsia - KZD) has the character of a "court or tribunal' in terms of Article 267 TFEU and that the Court of Justice, therefore, has jurisdiction to give a ruling on the questions referred to it by that body. ${ }^{40}$ Advocate General Kokott examined the relevant factors to determine if the KZD is a 'court or tribunal' for the purposes of the preliminary ruling procedure; the independence, the judicial activity and compulsory jurisdiction. After a detailed analysis of all these criteria, the Advocate General concluded that the KZD should be regarded as a court or tribunal within the meaning of Article 267 TFEU in the case at issue. ${ }^{41}$

The Court did not share this interpretation. It pointed out that the proceedings taking place before the KZD may originate in an initiative of the KZD itself, the KZD may join the proceedings of its own motion, other persons than those expressly appointed by the party which has brought the action before it, where an action is brought against a decision of the KZD, that body has the status of defendant before the administrative court called on to give a ruling on that application. Furthermore, if the decision of the KZD is annulled by the administrative court, that body may appeal against the decision to annul before the Varhoven administrative sad, if an action is brought against a decision of the KZD, it is possible for that body to revoke that decision, if the party to whom the decision is addressed is favourable. ${ }^{42}$

Taking into account these legal facts, the Court concluded that the decision of the KZD 'is similar in substance to an administrative decision and do not have a judicial nature within the meaning of the case-law of the Court relating to the concept of 'court or tribunal' in within the meaning of Article 267 TFEU, consequently the Court does not have jurisdiction to rule on the question referred by it.'

We are of the opinion of Mathias Möschel, who considers that '(L)egally speaking, both solutions are equally plausible and motivated, even though Advocate General Kokott's assessment is more detailed.' In our view, the Court, albeit in a legally correct manner, chose the interpretation which resulted in leaving important questions on racial discrimination unanswered. ${ }^{43}$

More recently, in Margarit Panicello 'Advocate General Kokott concluded that the referring body (Secretarion Judicial) is judicial' is nature. ${ }^{44}$ The Commission, as in Belov, shared this view.)

38 Idem. paras. 35-36.

39 C-349/11, Valeri Hariev Belov v CHEZ Elektro Bulgaria and others (ECLI:EU:C:2013:48).

40 Ibid, para 37.

41 Opinion of Advocate General Kokott, delivered on 20 September 2012, (ECLI:EU:C:2012:585) paras. 23-50.

42 Belov, paras. 47-50.

43 Möschel (2013) 1433-50.

44 Opinion of Advocate General Kokott (ECLI:EU:C:2016:696) para. 95. 
The Court did not follow its Advocate General. Referring to the uncertainty expressed by the Secretario Judicial itself and the decision of the Spanish Constitutional Court, it held that the proceedings in question are administrative and not judicial in nature. It also found that the referring body is not independent because it is required to comply with instructions from its hierarchical superior. ${ }^{45}$ Consequently, the Court concluded that it has no jurisdiction to answer the request for preliminary ruling submitted by this body because it not a 'court or tribunal' in the special context of the main proceedings.

Just like in Belov, the Court's reasoning is 'equally plausible and motivated' but considering the other side, the following arguments might have to be considered:

It is clear that the opinion of the Advocate General does not bind the judges, in both cases they had a coherent legal reasoning in favour of the admissibility before them, so the Court was not 'constrained' to reject the reference. The decision to do so, leaving the question for the interpretation of the EU law unanswered, may be classified as passivism.

The referring body has to be a court or tribunal of a Member State. This qualification has been refused in Miles. ${ }^{46}$ The Court, rejecting the arguments of Advocate General Sharpston, emphasized that the referring body, the Complaints Board of the European Schools, was a body of an international organization. This was created by the Member States of the Union, and despite the functional links it has with them, remained formally distinct from both the Union and the Member States. The result is as Wahl and Prete state '...is that a court created for the benefit of the EU institutions, located in the Union, and adjudicating disputes brought by EU citizens, is obliged to apply EU principles but not permitted to ask any clarification as to the interpretations of those principles. ${ }^{2} 7$

\subsubsection{EU law does not apply to the case before the national court- the Court does not have jurisdiction}

According to Article 267 TFEU, the Court has jurisdiction to interpret EU law when it is applicable to the legal dispute before the national court, when the facts of the case come under the scope of EU law. If the referring court fails to demonstrate this, the Court will declare the reference inadmissible. ${ }^{48} \mathrm{~A}$ general rule is that the Court does not have

45 C-503/15, Margarit Panicello (ECLI:EU:C:2017:126) paras. 26-43.

46 C-196/09, Miles and Others (ECLI:EU:C:2011:388).

47 Wahl and Prete (2018) 529. For the analysis of this case from a different perspective, see Jacob (2014) 135-37.

48 Examples from 2017:C-560/15, Europa Way and Persidera (ECLI:EU:C:2017:593) para. 34-48, C-247/16, Schottelius (ECLI:EU:C:2017:638). In Rosneft the Estonian and Polish Governments and the Council considered that the request for validity of the act in question is inadmissible, because the referring court has not explained the connection between that question and the legal proceedings at the national level and were sceptical as to whether an answer is necessary. The Court took the view that the question is admissible. C-72/15, Rosneft (ECLI:EU:C:2017:236) paras. 48-57 Very recently in Diallo (C-246/17, Diallo [ECLI:EU:C:2018:171] paras. 24-31) the Court did not accept the Belgian Government's claim for inadmissibility maintaining that the situation of the applicant in the main proceeding does not come within the scope of the EU law. In C-274/16, flightright (ECLI:EU:C:2018:160) paras. 44-49 the Court dismissed the Commission's claim for inadmissibility based on this criterion. In 2018 the Court declared ex officio only one case as inadmissible on the ground that the request for preliminary ruling did not demonstrate that there is a connecting link between the subject matter or the circumstances of the dispute in the main proceedings and the EU law. (C-343/17, Fremoluc [ECLI:EU:C:2018:754]). 
jurisdiction to interpret national law. The Court will declare the question inadmissible if the referring court fails to demonstrate the connecting factors between national law and EU law. ${ }^{49}$ The activist Court created two exceptions to the general rule; the Dzodzi and the Nolan principles. In Dzodzi, ${ }^{50}$ the Court held that it has jurisdiction where the national law of a Member State refers to the content of the EU law provision in order to determine rules applicable to a situation which is purely internal to that State. In Nolan, ${ }^{51}$ the Court also held that it has jurisdiction to answer preliminary questions where, in regulating situations outside the scope of the EU measure concerned, national legislation seeks to adopt the same solutions as those adopted in that measure. It is clearly in the interest of the European Union that, in order to forestall future differences of interpretation, provisions taken from that measure should be interpreted uniformly. ${ }^{52}$

Unfortunately the application of these principles is not without controversy.

In Ynos ${ }^{53}$ the Hungarian court sought an interpretation of Article 6(1) of the Council Directive 93/13/EEC for the purposes of assessing the scope of rules of implementing national law. Advocate General Tizzano offered two alternatives to the Court: rejecting the question because of lack of jurisdiction, the facts in the main proceedings occurred before the Republic of Hungary acceded to the European Union, or answering it. ${ }^{54}$ The Court opted for the former. Given that the applicable Hungarian piece of legislation was adopted with express reference to the directive, the referring court finally decided the case in the light of the directive. There were serious critical views expressed in the literature commenting on the decision. ${ }^{55}$

In Sahyouni I, ${ }^{56}$ the Court stated that the recognition of a divorce decision delivered in a third country does not fall within the scope of EU law. Given that the order for reference does not contain any element capable of establishing the jurisdiction of the Court; on the basis of the Dzodzi or the Nolan principles, the Court declared that it has no jurisdiction to answer the questions referred by the OberlandesgerichtMünchen. Interestingly, one and half years later, in Sahyouni II, ${ }^{57}$ the same chamber of the Court answered the same question referred by the same national court. We postulate that the first decision may be classified as passivism.

49 From the recent case-law: C-427/16, CHEZ Elektro Bulgaria (ECLI:EU:C:2017:960) paras. $33-39$.

50 C-297/88 and C-197/89, Dzodzi, (ECLI:EU:C:1990:360).

51 C-583/10, Nolan (ECLI:EU:C:2012:638).

52 See examples from the recent case law: C-295/16, Europamur Alimentación (ECLI: EU:C:2017:782), C-327/16, Jacob and C-421/16, Lassus (ECLI:EU:C:2018:210), C-459/17, SGI (ECLI:EU:C:2018:501). In Solar Electric Martinique the Court found that the conditions of the exceptions are not met, consequently it does not have jurisdiction. C-303/16 Solar Electric Martinique (ECLI:EU:C:2017:1010) paras. 25-37.

53 C-302/04, Ynos (ECLI:EU:C:2006:9).

54 Opinion of Advocate General Tizzano delivered on 22 September 2005 (ECLI:EU:C:2005:576).

55 See among others Lenaerts (2005) 225. Kaleda (2004) 102-22. Láncos (2007) 87-97., Bobek implicitly suggested that perhaps the reason behind this decision could have been an intention to discourage requests for preliminary ruling from the new Member States and this created a window of opportunity to cut back on the deadlock. Bobek (2014) 9 .

56 C-281/15, Sahyouni (ECLI:EU:C:216:343).

57 C-372/16, Soha Sahyouni v. Raja Mamisch (ECLI:EU:2017:988). 


\subsubsection{The national measure does not come within the scope of the EU Charter of Fundamental Rights - the Court does not have jurisdiction}

Under Article 51(1) of the Charter, the provisions of the Charter are addressed to the Member States only when they implement EU law. Like Article 51(2) of the Charter, Article 6(1) TEU states that the provisions of the Charter do not extend the competences of the Union in any way. According to the settled case-law of the Court, the fundamental rights guaranteed in the legal order of the European Union are applicable in all situations governed by EU law but not outside such situations. The Court has observed that it has no power to examine compatibility with the Charter of national legislation outside the scope of EU law. When a legal situation does not come within the scope of EU law, the Court has no jurisdiction to rule on it and any provisions of the Charter relied upon cannot, of themselves, form the basis for such jurisdiction. ${ }^{58}$

This line of case law is not without controversy. We agree with Lang that in Érsekcsanádi Mezőgazdasági ${ }^{59}$ that the Court was too severe in construing the scope of Article 17 (Right to property) of the Charter. Its narrow interpretation, which resulted in a declaration of lack of jurisdiction, deprived the applicant in the main proceedings of the loss of profit it suffered in terms of a national measure clearly adopted in order to implement an EU act. ${ }^{60}$

The Court, completely correctly, systematically rejected the references from Romanian courts asking the compatibility of national legislation with the Charter. The national courts failed to show that the respective legislations were in fact adopted as austerity measures in the framework of an EU financial assistance program to Romania. ${ }^{61}$ However, it is possible to agree with Markakis and Dermine, who maintain that '(T)he Court could have displayed more proactivity, and sought to reformulate the questions or rearticulate the referrals, as it had done in many other cases....This strict stance, ...was highly problematic from constitutional perspective. It served to obscure the supranational inspiration of the austerity plans and consolidation programmes implemented in various EU countries during the financial debt crisis, artificially inflated the actual autonomy and discretion retained by domestic authorities in those countries, and hence allowed the EU institutions to evade judicial scrutiny for their actions in the bailout context. ${ }^{\prime 62}$ From our perspective, the question arises if this 'lack of proactivity' does not amount to judicial passivism.

58 C-617/10, Åkerberg Fransson, para. 22. For the recent case-law see C-508/16, Boudjellal (ECLI:EU:C:2017:6), Order of the Court in Case C-177/17, Demarchi Gino (ECLI:EU:C:2017:656).

59 C-56/13, Érsekcsanádi Mezőgazdasági (ECLI:EU:C:2014:352).

${ }^{60}$ Lang (2015) 89-99.

${ }^{61}$ C-434/11, Corpul National al Politistilor v. MAI (ECLI:EU:C:2011:830), C-134/12, MAI et al. v. Corpul National al Politistilor (ECLI:EU:C:288), C-462/11, Cozman v. Teatrul Municipal Targoviste (ECLI:EU:C:831).

62 Markakis and Dermine (2018) 662. 


\subsubsection{The Court's resistance to the temptation of passivism}

According to well-established case law, questions related to EU law enjoy a presumption of relevance. ${ }^{63}$ The Court may refuse to rule on a question referred for a preliminary ruling by a national court only where it is quite obvious that the interpretation of EU law that is sought bears no relation to the actual facts of the main action or its purpose, where the problem is hypothetical, ${ }^{64}$ or where the Court does not have before it the factual or legal material necessary to give a useful answer to the questions submitted to it (Article 94 of the Rules of procedure inadmissibility). ${ }^{65}$

Wahl and Prete suggested that in the last years the Court assesses more intensely the requirements included in the Rules of Procedures. ${ }^{66}$ In 2017, the 'new rigour' of the Court, as far as 'Article 94 inadmissibility' is concerned, continued: 9 requests for preliminary ruling has been declared - in form of order of the Court - as manifestly inadmissible because of the '(I)nsufficient information regarding the factual and legal context of the dispute in the main proceedings and lack of grounds justifying why an answer to the questions referred is necessary.' In 2018 we found seven orders of this kind. ${ }^{67}$

The Member States governments often debate the admissibility of questions referred to the Court. The Court is clearly reluctant vis-à-vis this argument. In 2017 the Court rejected these kind of pleas of the Member States' governments and answered the question(s) in no less than 22 cases. In 2018 the trend continued: in 34 (!) cases the submissions maintaining inadmissibility were refused by the Court. Maybe the strongest opposition of the Court to admitting the claim for inadmissibility occurred in Liga van Moskeeën en

63 The standard formula: '(Q)uestions relating to EU law enjoy a presumption of relevance. The Court may refuse to rule on a question referred for a preliminary ruling by a national court only where it is quite obvious that the interpretation of EU law that is sought bears no relation to the actual facts of the main action or its purpose, where the problem is hypothetical, or where the Court does not have before it the factual or legal material necessary to give a useful answer to the questions submitted to it' (judgment of 7 February 2018, American Express, C304/16, [EU:C:2018:66], para. 32 and the case-law cited).

${ }^{64}$ C-392/16, Marcu (ECLI:EU:C:2017:519), C-3/17, Sporting Odds (ECLI:EU:C:2018:130) paras. 50-51, C-107/17, Aviabaltika (ECLI:EU:C:2018:600) paras. 39-43, C-152/17, Consortio Italian Management e Catania Multiservizi (ECLI:EU:C:2018:264) paras. 20-40, C-93/17, Weiss and Others (ECLI:EU:C:2018:1000) paras. 159-167).

${ }^{65}$ Article 94 of the Rules procedures of the Court of Justice (Content of the request for a preliminary ruling)

'In addition to the text of the questions referred to the Court for a preliminary ruling, the request for a preliminary ruling shall contain: (a) a summary of the subject-matter of the dispute and the relevant findings of fact as determined by the referring court or tribunal, or, at least, an account of the facts on which the questions are based; (b) the tenor of any national provisions applicable in the case and, where appropriate, the relevant national case-law; (c) a statement of the reasons which prompted the referring court or tribunal to inquire about the interpretation or validity of certain provisions of European Union law, and the relationship between those provisions and the national legislation applicable to the main proceedings.'

${ }^{66}$ See also Gimbergen (2015) 65-66.

67 C-472/16, Colino Sigüenza (ECLI:EU:C:2018:646) paras. 56-62, C-589/16, Filippi and Others (ECLI:EU:C:2018:417), C-190/18, SNCB (ECLI:EU:C:2018:355), C-24/18, Bán (ECLI: EU:C:2018:376), C-252/17, Vadillo González (ECLI:EU:C:2018:202), C-90/18, HBOR (ECLI: EU:C:2018:685), C-472/17, Di Girolamo (ECLI:EU:C:2018:684). 
Islamitische organisaties $^{68}$ in which not only the Flemish Region, the Netherlands and the United Kingdom's governments but also the Council and the Commission expressed doubts as to the admissibility of the question of validity.

The European Commission, which regularly makes observations in Article 267 procedures, also submitted, with others or alone, the claim for inadmissibility of the question(s) referred for preliminary ruling several times. In 2017 the Commission's arguments were accepted in one case ${ }^{69}$ and rejected in 6 cases. In Asociación Profesional Elite Taxi, ${ }^{70}$ as well the Commission, the Spanish, the Greek, the Polish, the Finnish and the Dutch Governments and the EFTA Surveillance Authority raised doubts, in vain, about the admissibility. In 2018 the Court took the opposite view and declared the questions admissible in 8 cases. ${ }^{71}$ In two American Express cases, ${ }^{72}$ beside the Commission, the European Parliament and Council also maintained that the referral is wholly inadmissible. The Court did not reject the request, despite the Advocate General also argued in favour of inadmissibility in American Express I. ${ }^{73}$ In Deichmann the Commission submitted that the applicant was entitled to requesting the EU Courts to annul the regulation at issue so that it should not be allowed to circumvent the time limit, by now pleading the invalidity of that regulation before the referring court. The Court adopted the opposite view, declaring that the regulation was adopted after the action had been brought before the referring court. The applicant seeks to defend itself, not to circumvent the time limit in Art. 263 TFEU. ${ }^{74}$ The Commission's argument against admissibility has been followed by the Court only in two cases. In Georgsmarienhütte and Others ${ }^{75}$ the applicants in the main proceedings were undoubtedly entitled to bringing an action for annulment before the General Court, but they did not exercise this right, consequently, under the TWD Textilwerke principle, ${ }^{76}$ the validity of the contested EU act was not properly challenged before the referring national court, and the request was considered inadmissible. In Renerga the Court, after asking further clarification from the referring court, declared that those provisions of EU law whose interpretation was sought, were not applicable, either directly or indirectly, to the circumstances of the case in the main proceedings and that, consequently, all of the

68 C-426/16, Liga van Moskeeën en Islamitische Organisaties Provincie Antwerpen and Others (ECLI:EU:C:2018:335) paras. 27-36.

${ }^{69}$ C-97/16, Pérez Retamero (ECLI:EU:C:2017:158) paras. 19-30.

70 C-434/15, Asociación Profesional Elite Taxi (ECLI:EI:C:2017:981) paras. 22-32.

71 C-518/15, Matzak (ECLI:EU:C:2018:82) paras. 23-26, C-64/16, Associação Sindical dos Juízes Portugueses (ECLI:EU:C:2018:117) paras. 19-26, C-259/16, Lazio (ECLI:EU:C:2018:370) paras. 62-68, C-528/16, Confédération paysanne and Others (ECLI:EU:C:2018:583) paras. 70-76, C-545/16, Kbota (UK) and EP Barrus (ECLI:EU:C:2018:101) paras. 17-21, C-643/16, American Express (ECLI:EU:C:2018:67) paras. 16-32, C-149/17, Bastei Lübbe (ECLI:EU:C:2018:841) paras. 23-25, C-238/17, C-216/17, Autorità Garantedella Concorrenza e del Mercato - Antitrust and Coopservice (ECLIEU:C:2018:1034) paras. 35-43.

72 C-304/16, American Express I (ECLI:EU:C:2018:66), paras. 30-48, C-643/16, American Express II (ECLI:EU:C:2018:67) paras. 16-32.

73 Opinion of Advocate General Campos Sánchez-Bordona in Case C-304/16, American Express (ECLI:EU:C:2018:524) paras. 26-48.

74 C-256/16, Deichmann (ECLI:EU:C:2018:187) paras. 38-42.

75 C-135/16, Georgsmarienhütte and Others (ECLI:EU:C:2018:582) paras. 12-44.

76 C-188/92, TWD Textilwerke Deggendorf (ECLI:EUC:1994:90). 
questions referred in the context of that case are hypothetical, which renders the request inadmissible. ${ }^{77}$

Parties in the main proceedings also argued, generally in vain, against the admissibility of the request for preliminary ruling before the Court. In 2017 the Court declared requests admissible in 6 cases and inadmissible only in two. ${ }^{78}$ In 2018 in 12 cases the Court felt that the referral is admissible, ${ }^{79}$ and only in one case did it admit that the referred questions are inadmissible. ${ }^{80}$

Another type of not answering the referred question is delivering a judgment but actually avoiding important questions asked by the national court. ${ }^{81}$

\subsection{Express lack of jurisdiction in the Treaty}

Rosneft also raised the hard question of the jurisdiction of the Court to rule on the validity in the framework of the preliminary ruling procedure of an act adopted on the basis of the provisions relating to the CFSP. ${ }^{82}$ The United Kingdom Government, the Czech, Estonian, French and Polish Governments and the Council considered that the Court does not have jurisdiction to give a preliminary ruling on the validity of Decision 2014/512 CFSP. The Commission took the view that conditions of the exceptional jurisdiction of the Court are not met. The Court, relying on Articles 19, 24 and 40 TEU, Article 275 TFEU, and Article 47 of the Charter, ruled that it has jurisdiction to rule. ${ }^{83}$

The Court for once refused to yield to the temptation of passivism.

\subsection{Unjustified deference to the national court or to the EU or Member States legislators}

Another kind of judicial passivism in its narrow sense is the unjustified deference to the EU or Member States' legislators or to the national court. Azoulai suggests, naming the phenomenon 'minimalism', that in some situations the Court uses the 'technique of

77 C-238/17, Renerga (ECLIEU:C:2018:905) paras. 19-29.

78 97/16, Pérez Retamero (ECLI:EU:C:2017:158), C-560/15, Europa Way and Persidera (ECLI:EU:C:2017:593).

79 C-103/16, Porras Guisado (ECLI:EU:C:2018:99) paras. 29-32, C-179/16, F.Hoffmann La Roche and Others (ECLI:EU:C:2018:25) paras. 43-47, C-297/16, CMVRO (ECLI:EU:C:2018:141) paras. 34-37, C-518/16, ZPT (ECLI:EU:C:2018:126) paras. 17-33, C-574/16, GrupoNorte Facility (ECLI:EU:C:2018:390) paras. 31-34, C-25/17, Jehovan Todistajan (ECLI:EU:C:2018:551) paras. 30-33, C-51/17, OTP Bank and OTP Faktoring (ECLI:EU:C:2018:750) paras. 3-45, C-195/17, Krüsemann and Others (ECLI:EU:C:2018:258) paras. 23-28, C-268/17, AY (ECLI:EU:C:2018:602) paras. 23-31, C-331/17, Sciotto (ECLI:EU:C:2018:859) paras. 26-29, C-512/17, HR (ECLI:EU: C:2018:513) paras. 31-37, C-569/16, Bauer (ECLI:EU:C:2018:871) paras. 20-29.

80 C-492/17, Rittinnger and Others (ECLI:EU:C:2018:1019) paras. 35-52.

81 Pech (2012) 1841-80, Krommendijk (2019) 401-04.

82 Article 275 TFEU, in Section 5, states that 'The Court of Justice of the European Union shall not have jurisdiction with respect to the provisions relating to the common foreign and security policy nor with respect to acts adopted on the basis of those provisions.

However, the Court shall have jurisdiction to monitor compliance with Article 40 of the Treaty on European Union and to rule on proceedings, brought in accordance with the conditions laid down in the fourth paragraph of Article 263 of this Treaty, reviewing the legality of decisions providing for restrictive measures against natural or legal persons adopted by the Council on the basis of Chapter 2 of Title V of the Treaty on European Union.'

${ }^{83}$ Rosneft (footnote 42) paras. 58-81. 
retreating from decision, leaving sensitive issues to the national court or the national or Union legislators to solve'. ${ }^{84}$ Beck's understanding of deference is explicitly 'anti-activist', involving the 'non-communautaire' exercise of judicial discretion, being less assertive and integrationist in those areas where national governments and/or national courts have shown greater political- constitutional sensitivity. ${ }^{85} \mathrm{He}$ differentiates between strong deference (the Member State wins in annulment cases, restrictive interpretation of a basic EU law principle), limited deference (recognising or extending an exception to a broadly integrationist principle), weak deference (the Court rules on general questions of principle, but leaves the determination of facts and/or the proportionality assessment to the national court) and temporal deference (temporal limitation of the decision). ${ }^{86}$

Deference to these actors may well be justified in most of the cases but there are cases where the deference is clearly unjustified. This may arise when the Court leaves the decision for the national court, while the referring court put all circumstances of the case in its order for reference. ${ }^{87}$

\subsubsection{Deference to the referring national court}

The Court's decision to not give (complete) answers is well-founded in a number of cases in which the Court does not have enough information about the legal or factual circumstances of the case in relation to which the question of interpretation was referred to it by the national court. This can arise very often in cases related to proportionality, when the Court defers the assessment of the proportionality of the national measure in question to the national court (or to the national authorities). Consequently, judicial deference is judicial passivism only in cases where the Court is in a better position than the national court in the assessment of the proportionality of the measure in question, so that deference is a way to avoid giving an answer. ${ }^{88}$

Comparing decisions adopted in Grand Chamber in 1997 and 2010 Sarmiento found that the proportion of minimalist judgments delivered in preliminary ruling procedures increased importantly (from $17 \%$ to $49 \%$ ). ${ }^{89}$

We analyzed the judgments delivered with reference to preliminary rulings by the Grand Chamber in the years 2008-2018 and found that the proportion of judgments leaving some margin of appreciation for the referring court ${ }^{90}$ shows a remarkable stability

84 Azoulai (2013) 178.

${ }^{85}$ National sensitivities are more likely to be triggered in the following areas: conflicts between EU law and national constitutional and human rights law, conflict between EU law and national criminal law, areas of budgetary sensitivity, in particular social security law, direct taxation, employment policy, national laws of national extradition, immigration and sensitive issues of national cultural and linguistic identity, educational policy, public morality, areas of important 'vested' and well organised professional interests, organisation of the civil service, national procedural laws. Beck (2012) 351-54.

${ }^{86}$ Beck (2012) 350-90.

${ }^{87}$ Krommendijk (2019) 403.

${ }^{88}$ That is the case, for example, in judgments in which the Court states that there has been an infringement of free movement provisions, "unless the referring court, having assessed all the relevant evidence submitted by the competent authorities, finds that that legislation is justified in the light of the objective of protection' or, for example, public health. (Bressol and Others, Pammer and Hotel Alpenhof, Bozkurt, Weald Leasing) Sarmiento (2012) 21-22.

89 Sarmiento (2012) 27-28 in footnote 65.

90 The generally used formula says: 'It is for the referring court to determine' (for example C-365/13, International Stem Cell, ECLI:EU:C:2014:2451, point 36). 
between 2008 and 2016. The percentage remained between $33 \%$ and $40 \%$ for seven years. ${ }^{91}$ Combining judgments delivered in the last two years of 2017 and 2018, is in the same range of proportion $(37,5 \%){ }^{92}$

\subsubsection{Deference to the Member States' legislator}

Sarmiento under the label 'minimalism' submitted that ' $(\mathrm{G})$ ranting - not to the national court, but to the rule-making authorities of a Member State - the power to decide on the proper answer that the case may need. In this strand of minimalist adjudication the CJEU is not relying on the referring court, but on the legislative branch of the Member State from where the reference is coming, thus confirming that EU law still grants a margin of regulatory appreciation that has not been yet fulfilled. This is a common feature of cases involving transposition of directives or framework decisions in which the Court declares that the Member State has not breached EU law. ${ }^{93}$

We believe that in cases where the Court answered the questions asked, it fulfilled its judicial role, consequently, it may not be classified as passivism. This does not mean that the referring court, which questioned the compliance of national legislation applicable in the main proceedings with EU law, is necessarily satisfied with the answer.

Theoretically, only a decision whose reasoning is not completely convincing and/or clearly influenced by extra-legal considerations may be qualified as a manifestation of judicial passivism.

In Cinéthèque the Court declined to test the compatibility of the French legislation in question with the freedom of expression on the ground that the French legislation at issue fell within the powers of the national legislator:

'The plaintiffs and the interveners in the main action also raised the question whether Article 89 of the French law on audio-visual communication was in breach of the principle of freedom of expression recognized by Article 10 of the European Convention for the Protection of Human Rights and Fundamental Freedoms and was therefore incompatible with Community law.

Although it is true that it is the duty of this Court to ensure observance of fundamental rights in the field of Community law, it has no power to examine the compatibility with the European Convention of national legislation which concerns, as in this case, an area which falls within the jurisdiction of the national legislator. ${ }^{94}$

The Court's reasoning is somewhat misleading; the Court examined the compatibility of the national measure in question with Article 30 EC Treaty. Consequently, the area fell within the jurisdiction of the Court. What it refused to control was the compatibility of the national legislation with the fundamental right enshrined in the European Convention. Given that the Court admits its power concerning the assurance of fundamental rights, its refusal, deferring the control of compatibility with fundamental rights to the national legislator, seems to be a good example of judicial passivism. ${ }^{95}$

91 In 200913 from 19 judgments (68\%) left explicitly some margin of appreciation to the referring court.

${ }^{92}$ In 2017 from the 26 judgments delivered in preliminary ruling cases 6 ruled on deference to the referral court (23\%), in 2018 the respective figures were 54/24 (44\%).

93 He refers to Gueye, Eredics and Sápi, Dell'Ortoand Katz. Sarmiento (2012) 22.

94 Joined cases 60 and 61/84, Cinéthèque v Fédération nationale des cinémas français (ECLI:EU:C:1985:329) paras. 25-26.

95 See also in this sense Beck's comments on Dory v Germany (C-186/01, Dory v Germany (ECLI:EU:C:2003:146) Beck (2012) 375. 


\subsection{Inadmissibility in actions for annulment cases}

\subsubsection{Lack of standing}

If the Court declares that the applicant in an annulment procedure under Article 263 TFEU has no standing, the legal dispute on the legality of the EU act in question remains unsolved. If the legal reasoning on the lack of standing of a particular group of litigants used by the Court is weak or highly debatable, this may pave the way to judicial passivism.

Maybe the most striking example of this kind of passivism is the standing of private persons in annulment procedures under Article 263 TFEU. The restrictive interpretation given in Plaumann ${ }^{96}$ has been extensively discussed in the literature, ${ }^{97}$ argued against in an Advocate General's opinion ${ }^{98}$ and also in a judgment of the General Court. ${ }^{99}$ This rigour made it possible to qualify as inadmissible a number of actions even in cases where the really complete system of remedies would have required otherwise.

The Court did not cede and called the Member States to amend the Treaty instead. ${ }^{100}$ This is what the Member States did in Lisbon, leaving some margin of interpretation however for the Court for another restrictive interpretation. ${ }^{101}$ This case falls also within the category of 'conservatism as passivism'.

\subsubsection{The act is not an act according to Article 263}

Section 1 showed that the General Court dismissed the action in the Turkey-EU Statement cases. Goldner Lang maintains, with others, that the document could have been qualified as an act in the meaning of Article 263 TFEU, consequently the dismissal was actually a refusal to decide on the lawfulness of the document in question, representing judicial passivism. It should not be neglected that the document in question is an integral part of the efforts of the European Union in order to slow down the huge migration flow from the Middle East towards Western Europe.

Reference can also be made to the earlier Commission v Council case, ${ }^{102}$ in which the Court's assessment of the admissibility was also questionable.

The European Monetary Union was based on the conviction that the common currency's inflation has to be maintained at a low rate. One of the guarantees of this was included into the Treaty itself - the Member States are obliged to maintain their public deficit under a certain limit. The Treaty also contained (and still contains) procedures in case of a breach of this obligation. The Commission, as the guardian of the Treaty, initiated procedures against Germany (the main proponent of these rules) and France, both of them encountering excessive deficit. The Council, instead of adopting the necessary measures

96 ‘...seules les personnes qui sont affectées par une décision en raison de leur individualité ou de leur situation particulière peuvent être considérées comme individuellement concernées aux fins d'un recours.' Case 25/62 Entreprise Plaumann v Commission (ECLI:EU:C:1963:17).

97 Rasmussen (1980) 112-127, Arnull (1995) 7-49, Ragolle (2003) 90-101, Waelbroek (2002)

3-8, Varju (2003) 99-127, Korkea-aho (2015) 140.

98 Opinion of Advocate General Jacobs C-50/00P, Unión Pequeños Agricultores v. Council (ECLI:EU:C:2002:197).

99 T-177/01, Jégo-Quéré v Commission (ECLI:EU:T:2002:112).

100 C-263/02 P, Commission v Jégo-Quéré (ECLI:EU:C:2004:210) para 41.

101 Van Malleghem and Baeten (2014) 1187-1216, See also C-274/12P, Telefónica, ECLI:EU:C:2013:852.

102 C-27/04, Commission v Council (ECLI:EU:C:2004:436). 
in order to eliminate the budget deficit, merely adopted 'conclusions' with the same goal. The Commission brought action against the Council: It asked the Court to annul, first, the decision of the Council not to adopt the formal instruments contained in the Commission's recommendations pursuant to Article 104(8) and (9) EC and, second, the Council's conclusions in so far as they involve holding the excessive deficit procedure in abeyance, recourse to an instrument not envisaged by the Treaty and modification of the recommendations decided on by the Council under Article 104(7) EC.

The Council contended that the Court should either declare the action inadmissible or dismiss it.

It seems quite obvious that the Court had sufficient legal arguments, presented by the Commission and the Advocate General, ${ }^{103}$ to declare the action admissible, fulfilling its judicial function in its entirety. The Court (the judges in Full Court) considered, first, that the Council's decision, not to decide, was not an act open to challenge (inadmissible) $)^{104}$ and, second, it held that the Council's conclusions were adopted in a manner contrary to the procedural rules laid down in Article 104(7) and (13) EC had to be annulled.

As it has been suggested in the literature, this 'passivist' approach was due to the political reasonableness of the Court in times of economic imbalance, correcting the rigidity of the primary and secondary EU legislation.

The 'reasonableness' of the Courts was manifested in the context of deep financial crisis in one of the Euro-zone Member States (Cyprus) in Ledra.

Ledra Advertising applied before the General Court for annulment of the Memorandum of Understanding (MoU) concluded between the Republic of Cyprus and the European Stability Mechanism (ESM) and secondly, for compensation for damage allegedly suffered as a result of the Memorandum of Understanding and an infringement of the Commission's supervisory obligation. The ESM is an international organisation outside the EU legal system, but with the participation of EU institutions (the Commission and the European Central Bank). The General Court dismissed the action. In its reasoning it argued that the act in question is not an act of the European Union, so it has no jurisdiction to rule on the non-contractual liability of the Union. The same is the case with the annulment of the act in question. The Court rejected the claim concerned that the Commission has failed to ensure that MoU was in conformity with EU law, because of the lack of necessary certainty that the damage was actually caused by the inaction alleged against the Commission. ${ }^{105}$

The case on appeal reached the Court of Justice. ${ }^{106}$ Following its Advocate General, it also considered that the fact that one or more institutions of the European Union may play a certain role within the ESM framework (the European Commission Cypriot authorities), does not alter the nature. The European Commission signed the MoU on behalf of the ESM, the Commission and the ECB participated in the negotiations with the Cypriot authorities.

103 C-27/04, Commission v Council, View of Advocate General Tizzano (ECLI:EU:C:2004:313).

104 '...by making this part of the action inadmissible, the Court avoids having to consider any implied decision that the action of the recalcitrant states was effective and having to engage in any substantive analysis of the effectiveness or otherwise of national fiscal policy - a difficult analysis for economists let alone judges. Thus the conclusion is a neat but it seems to fly in the face of the original spirit and letter of Reg. 1467/97, to some extent undermining the aim of that Regulation and implicitly giving ECOFIN more room for manoeuvre.' Maher (2004) 831-41. See also Chaltiel (2004) 643-55. 105 T-289/13, Ledra Advertising Order of the General Court 10 November 2014. (ECLI: EU:T:2014:981).

106 C-8/15 P, Ledra Advertising (ECLI:EU:C:2016:701). 
However, this does not alter the nature of the acts of the ESM, which fall outside the EU legal order. Therefore, the application for annulment of the MoU could not be admitted. Concerning the non-contractual liability of the EU, based on the Commission's obligation to ensure that the EU law (including the right to property included in the EU Charter of Fundamental Rights) the Court admitted that the MoU violated this right but, given the importance of the stability of the Euro-zone Member States' banking systems, the measure does not constitute a disproportionate and intolerable interference impairing the very substance of the appellants' right to property.

The legal reasoning of the EU Courts is fairly well-established, especially if the 'grey zone' between international public law and the EU law in which the ESM has been created ${ }^{107}$ is disregarded, and the 'real world' facts, in the wording of the appellant, '( $t$ )he effective cause of the diminution in value of their deposits was the conditions attached to the financial assistance facility provided to the Republic of Cyprus and the process by which those conditions were required by the Commission and the ECB. The Republic of Cyprus was compelled by the Commission and the ECB to adopt Decrees No 103 and No 104, under the aegis of officials from those institutions who intervened as a matter of urgency for that purpose.' 108

The EU Courts (the general Court and the Court of Justice) did not have to face any difficulties declaring inadmissible the actions for annulment against the Euro group statement of 25 March 2013, concerning, in particular, the restructuring of the banking sector in Cyprus arguing that Euro group is not empowered to adopt legally binding acts, it is not a formation of the Council. ${ }^{109}$

\section{PASSIVISM IN A BROAD SENSE}

The Court's attitude in a number of cases is contrary to the activist judicial behaviour (that is, promoting the constitutionalisation of the EU legal system, the effectiveness of EU law, the enlarging the scope of EU law, through textual or teleological interpretation), and refrains from the necessary reforms or narrows the scope of EU law. These kind of phenomena are classified as judicial passivism in the broad sense.

\subsection{Conservatism as passivism}

Courts, except perhaps in short revolutionary periods, are conservative by nature. They are linked to the written law (formalism, textualism) and follow their earlier judgments (precedents).

Gunnar Beck explains, in connection with the ECJ, that 'The normative constraint imposed by precedents reflects a strong normative presumption in all legal systems that courts within the same legal system should decide relevantly similar cases consistently, unless there is good reason not to do so or a material difference between them which justifies judicial departure from previous decision. It follows that once it has ruled on an

107 '(A)s for the EMU, its new composite regulation is not simply an exercice in the differentiation within the context of a unitary framework. It is a legal and institutional framework that may directly conflict or be inconsistent with the EU framework.' Chiti and Teixeira (2013) 696.

108 C-8/15 P, Ledra Advertising (ECLI:EU:C:2016:701) para. 43.

109 Joined Cases C105/15 P to C109/15 P, Mallis and Malli v Commission and ECB (ECLI:EU:C:2016:702). 
issue, the Court of Justice is constrained by its own previous rulings and indeed by its own words although to a lesser extent, and a much lesser extent in respect of the wording of its own rulings, than by the written norms of Union law. ${ }^{110}$

Schmidt goes one step further, using the market freedoms, arguing that in the case of the ECJ path-dependence can be observed. A path-dependent process is established by a precedent, together with its motivating or de-motivating impact on litigants. ${ }^{111}$

Kenney submits that the référendaires at the ECJ contribute to the legal consistency of the case law, which is important, because '(I)f the ECJ wants to ensure compliance with the law, it should only deviate from precedent for good legal and policy reasons, rather than because the current crop of judges failed to understand it.' ${ }^{112}$

Huyue Zhang suggests the same in case of career référendaires: 'Because these référendaires have the tendency to strictly to adhere to the Court's precedents, formality and style, they represent a force of conservatism and formalism at the Court.'113

What is considered 'conservatism as passivism' here is not merely a tendency to maintain the consistency of the law by following precedents or a path-dependent way; it is rather an open attitude of the judges at the Court to maintaining a legal position in spite of criticism coming from the legal academia and/or from the Court (General Court, Advocates General) itself.

In such cases, the Court of Justice actually did not refuse to decide, so it cannot be maintained that the Court did not fulfil its given task. That is why it does not qualify as passivism in a narrow sense of the term but its attitude, not changing, not moving, even if it would be possible, useful or logical, is a kind of conscious passivism.

Maybe the most striking example of this is the standing of private persons in annulment procedure under Article 263 TFEU, discussed above.

The Court's refusal to disclose pleadings lodged by one of the institutions in court proceedings to the public is also an example of conservatism. The text of Article 15 (3) TFEU only allows the non-disclosure but does not forbid is closure. Not only the interested party but also Advocate General Maduro argued in vain for public access to the pleadings of the parties. ${ }^{114}$

Some commentators also consider that the refusal of horizontal direct effect of directives is also due to a certain conservatism. ${ }^{115}$

Another interesting criticism comes from Kaupa, who maintains that the Court relies on old economic theories, which cannot correctly reflect the economic (and social) reality in which the Court makes its decisions. ${ }^{116}$ The Court, against the argument of a number of economists that the concept of predatory pricing cannot be maintained in every situation, maintained its earlier position. ${ }^{117}$

110 Beck (2012) 339. See also Jacob (2014), Tridimas (2012) 307-30.

111 Schmidt (2012) 10.

112 Kenney (2000) 596.

113 Huyue Zhang (2016) 103.

114 Joined Cases C-514/07.P, C-528/07.P. and C-532/07, API (ECLI:EU:C:2009:2) para.93-94, Opinion of Advocate General Poiares Maduro delivered 1 October 2009 Joined Cases C-514/07.P, C-528/07.P. and C-532/07, API, paras. 13-30.

115 For a recent review of literature see Fagioli (2018).

116 Kaupa (2013).

117 Sibony (2009) 192-93. 
The Court's rigid sticking to Mangold ${ }^{118}$ may also be considered conservatism as passivism. The commentator of Ajos $^{119}$ said '...in one reading, the second question asked by the SCDK simply requested the ECJ to reconsider and abandon Mangold. Such a proposal was certainly not new to the ECJ, and the ECJ may have considered the SCDK's question slightly out of time and place. That issue had now been fiercely debated for ten years by national courts, EU law scholars and advocates general. When Ajos arrived in September 2014, the ECJ had already had plenty of opportunities to reconsider Mangold, but consistently refused to do so.' 120

The Court's rigid position in Schul ${ }^{121}$ was also criticized. ${ }^{122}$ In this case the Court was given the opportunity to ease its own Foto-Frost doctrine ${ }^{123}$ but decided not to do so, opposing its Advocate General. ${ }^{124}$ The referring court asked the Court:

'Is a court or tribunal as referred to in the third paragraph of Article 234 EC also required under that provision to submit to the Court of Justice a question such as that set out below concerning the validity of provisions of a regulation where the Court of Justice has ruled that analogous provisions of another, comparable regulation are invalid, or may it refrain from applying the first-mentioned provisions in view of the clear analogies between them and the provisions declared invalid?'125

The Court's answer was a clear refusal:

'The third paragraph of Article 234 EC requires a court or tribunal of a Member State against whose decisions there is no judicial remedy under national law to seek a ruling from the Court of Justice on a question relating to the validity of the provisions of a regulation even where the Court has already declared invalid analogous provisions of another comparable regulation.' ${ }^{26}$

Korkea-Aho also criticizes the Court because it gives too much weight to the (old) representative democracy principle instead of relying on deliberative democracy which in several cases is more adequate to the real world. ${ }^{127}$

\subsection{Retreat}

Given that one characteristic of judicial activism is enlarging the scope of EU law, it seems justifiable to qualify as passivism in a broad sense of the term the jurisprudence in which the Court decided to step back from its earlier position narrowing the scope of it earlier judgment(s).

118 C-144/04, Mangold (ECLI:EU:C:2005:709).

119 C-441/14, Dansk Industri (DI) (ECLI:EU:C:2016:278).

120 Holdgaard, Elkan and Krohn Schaldemose (2018) 37.

121 C-461/03, Gaston Schul Douane-expéditeur (ECLI:EU:C:2005:742).

122 Coutron (2007) 491-511.

123 C-314/85 Foto-Frost (ECLI:EU:C:1987:452) Under this doctrine where a court or tribunal not subject to the third paragraph of Article 267 TFEU perceives that an act of a Union institution, body, office or agency is invalid, it may not make such a finding itself, but must seek a preliminary ruling from the Court of Justice.

124 Opinion of Advocate General Ruiz-Jarabo Colomer (ECLI:EU:C:2005:415).

125 C-461/03, Gaston Schul Douane-expéditeur (ECLI:EU:C:2005:742) para. 14.

126 C-461/03, Gaston Schul Douane-expéditeur (ECLI:EU:C:2005:742) point 1 of the operative part of the judgment.

127 Korkea-aho (2015). 


\subsubsection{Overruling}

The most obvious manifestation of such judicial decisions are the cases were the Court expressly or implicitly overruled its previous judgment. This does not mean that all overrulings can be classified as passivism. In a number of cases the Court even broadened the scope of EU law. ${ }^{128}$ The Court only expressly overruled its previous decision only in very few cases. Among the best known cases, Haag II was the first express overruling. ${ }^{129}$ Such readiness to sacrifice property rights in favour of free movement in HAG $\mathrm{I}^{130}$ was perceived as erroneous by Jacobs AG in HAG II. ${ }^{131} \mathrm{He}$ invited the Court to overrule its precedent and to make it clear that it was doing so. The Court followed and made the criterion of consent, rather than the criterion of common origin, the determinant factor in reliance on a trademark. What is important here is that the Court narrowed the scope of the free movement of goods, a fundamental freedom assured by EU law from the beginning of European integration. The other famous example of express overruling is Keck. ${ }^{132}$ Keck introduced a new approach to the interpretation of Article 30 (now Article 34 TFEU), making a distinction between rules concerning the physical characteristics of goods and rules concerning selling arrangements. In Dassonville and Cassis de Dijon the Court had interpreted the notion of restrictions on free movement of goods too broadly, so in Keck it declared:

'By contrast, contrary to what has previously been decided, the application to products from other Member States of national provisions restricting or prohibiting certain selling arrangements is not such as to hinder directly or indirectly, actually or potentially, trade between Member States within the meaning of the Dassonville judgment (Case 8/74 [1974] EC R 837), so long as those provisions apply to all relevant traders operating within the national territory and so long as they affect in the same manner, in law and in fact, the marketing of domestic products and of those from other Member States.' 133

\subsubsection{Stepping back from earlier position}

In Brasserie du Pêcheur-Factortame ${ }^{134}$ the Court established stricter conditions for the Member States liability for extra-contractual loss and damages caused by breach of EU law to private persons as it was determined in Francovich and Bonifaci ${ }^{135}$ The 'breach' had been changed to 'sufficiently serious breach' and the required causal link between the breach of EU law by the Member State and the loss or damages to the private person had been

128 Tridimas presents a number of examples of this: C-308/93, Cabanis Issarte, Bidar, overruling Lair and Brown v Rentokil Ltd, ${ }^{71}$ overruling Larsson, ${ }^{72}$ provided a more favourable interpretation of the Sex Equality Directive for pregnant employees, Metock overruling Akrich. Tridimas (2012) 318-20.

129 Tridimas (2012) 307-30.

130 C-192/73, Van Zuylen v HAG (ECLI:EU:C:1974:72).

131 C-10/89, CNL-Sucal v HAG (HAG II) (ECLI:EU:C:1990:359).

132 C-267/91, Keck and Mithouard (ECLI:EU:C:1993:905).

133 Ibid. para. 16.

134 Joined cases C-46/93 and C-48/93, Brasserie du Pêcheur v Bundesrepublik Deutschland and The Queen/Secretary of State for Transport, ex parte Factortame and Others (ECLI:EU:C:1996:79).

135 C-6/90, Francovich and Bonifaci v Italy (ECLI:EU:C:1991:428 ) para. 40. 
transformed into 'direct causal link'. ${ }^{136}$ These two 'clarifications' narrowed the scope of the Member States liability for damages under EU law.

The Court's retreat from its line of reasoning in Martinez Sala, Grzelczyk, Trojani ${ }^{137}$ concerning European citizenship rights in the Dano-Alimanovic case law is extensively documented. ${ }^{138}$

The European Court of Justice in the case Martinez Sala, then in Grzelczyk - with a wide, activist interpretation of the principle of prohibition on the ground of nationality asserted that Union citizenship has an independent legal meaning. In its latter judgment it declared:

'Union citizenship is destined to be the fundamental status of nationals of the Member States, enabling those who find themselves in the same situation to enjoy the same treatment in law irrespective of their nationality, subject to such exceptions as are expressly provided for.' 139

The magic was gone in Dano, ${ }^{140}$ in which the Court admitted the right of the Member States to limit Union citizens' access to the social benefits if they do not have any relationship with the labour market of the host Member State. The Court retreated from its earlier approach, which interpreted this right on the Union citizenship (TFEU Treaty), and limited it to a right based exclusively on secondary legislation (Directive 2004/38). ${ }^{141}$ Given that Dano corresponded well with 'benefit tourism', it was not obvious how the Court would decide in other factual situations.

The Alimanovic judgment ${ }^{142}$ gave a clear answer to this question. Without even referring to the 'fundamental status' of Union citizens it stated:

'It must first be recalled in this connection that, so far as concerns access to social assistance, such as that at issue in the main proceedings, a Union citizen can claim equal treatment with nationals of the host Member State under Article 24(1) of Directive 2004/38 only if his residence in the territory of the host Member State complies with the conditions of Directive 2004/38 (judgment in Dano, C333/13, EU:C:2014:2358, paragraph 69).

To accept that persons who do not have a right of residence under Directive 2004/38 may claim entitlement to social assistance under the same conditions as those applicable to nationals of the host Member State would run counter to an objective of the directive, set out in recital 10 in its preamble, namely preventing Union citizens who are nationals of other Member States from becoming an unreasonable burden on the social assistance system of the host Member State (judgment in Dano, C333/13, EU:C:2014:2358, paragraph 74). ${ }^{143}$

136 Joined cases C-46/93 and C-48/93, Brasserie du Pêcheur v Bundesrepublik Deutschland and The Queen/Secretary of State for Transport, ex parte Factortame and Others (ECLI:EU:C:1996:79) para. 51.

137 C-85/96, Martinez Sala (ECLI:EU:C:1998:217), C-184/99, Grzelczyk (ECLI:EU:C:2001: 458), C-456/12, Trojani (ECLI:EU:C:2004:488).

138 Iliopoulou-Penot (2016) 1007-36.

139 Grzelczyk, para. 31.

140 C-333/13, Dano (ECLI:EU:C:2014:2358).

141 Thym calls the Court's reasoning as 'interpretative conservatism'. Thym (2015) 249.

142 C-67/14, Alimanovic ( ECLI:EU:C:2015:597).

143 Alimanovic, paras. 49-50. See also case C-308/14, Commission v. United Kingdom (ECLI:EU:C:2016:436). The title of O'brian's case note is talking: The ECJ sacrifies EU citizenship in vain: Commission v. United Kingdom. O’brian (2017) 209-44. 
The retreat from 'civis europeus sum' to the 'homo oeconomicus' is certainly well identifiable. $^{144}$

The Court also stepped back from the standard rule that objectives of a purely economic nature cannot justify a restriction of free movement rights. ${ }^{145}$ Anew approach emerged in case law on access to medical services. The maintenance of the financial balance of a social security system may justify a barrier to the freedom of providing cross-border services. ${ }^{146}$

Another interesting example of retreat is the case law concerning the non-contractual liability of the European Union for damages caused by non-illegal (lawful) action or omission. In Dorsch Consult ${ }^{147}$ the Court did not exclude in special cases the existence of this kind of liability. ${ }^{148}$ Some years later in FIAMM - against the proposal of Advocate General Maduro - it declared:

'The Court's case-law enshrining, in accordance with the second paragraph of Article $288 \mathrm{EC}$, both the existence of the regime governing the non-contractual liability of the Community for the unlawful conduct of its institutions and the conditions for the regime's application is thus firmly established. By contrast, that is not so in the case of a regime governing non-contractual Community liability in the absence of such unlawful conduct. Contrary to what the Court of First Instance stated in the judgments under appeal, it cannot, first of all, be deduced from the case-law prior to those judgments that the Court of Justice has established the principle of such a regime.' ${ }^{149}$

144 Thym (2015) 17-50., Verschueren (2015) 363-90., Nic Shuibne (2015) 889-938., Varju (2018) 274-87., Martínez (2016) 263-76.

145 C-35/98, Staats secretaris van Financiën v B.G.M. Verkooijen (ECLI:EU:C:2000:294) para. 48:'accoording to the settled case law, aims of a purely economic nature cannot constitute an overriding reason in the general interest justifying a restriction of a fundamental freedom guaranteed by the Treaty'.

146 C-368/98, Vanbraekel and Others v. Alliance nationale des mutualités chrétiennes (ECLI:EU:C:2001:200) para 47 'It should be remembered that the Court has held that it cannot be excluded that the risk of seriously undermining the financial balance of a social security system might constitute an overriding reason in the general interest capable of justifying a barrier to the principle of freedom to provide services (Kohll, para 41).' For the problems arising for the burden of proof see: Nic Shuibhne, Maci (2013) 997-1006.

${ }^{147}$ C-237/98 P, Dorsch Consult Ingenieurgesellschaft mbH v. Council and Commission (ECLI:EU:C:2000:321).

148 '.. in the event of the principle of Community liability for a lawful act being recognised in Community law, a precondition for such liability would in any event be the existence of 'unusual' and 'special' damage (see Joined Cases 9/71 and 11/71 Compagnied'Approvisionnement, de Transport et de Crédit et GrandsMoulins de Paris v Commission [1972] ECR 391, paras. 45 and 46, and Case 59/83 Biovilac v European Economic Community [1984] ECR 4057, para 28). It follows that the Community cannot incur non-contractual liability in respect of a 'lawful' act, as in the present case, unless the three conditions referred to in the two preceding paras., namely the reality of the damage allegedly suffered, the causal link between it and the act on the part of the Community institutions, and the unusual and special nature of that damage, are all fulfilled.' Dorsch Consult paras. 18-19.

149 C-120/06P, FIAMM and Others v Council and Commission (ECLI:EU:C:2008:476) paras. $167-68$. 


\section{CONCLUSIONS}

According to the generally accepted understanding, judicial activism arises when a court behaves improperly, straying beyond the limits of the judicial function and acting like a legislature.

The Court of Justice of the European Union has long been criticized for its judicial activism. The literature - and the members of the Court themselves - qualified decisions as activist judgments which introduced new legal institutions, new legal principles into the EU legal order and/or fulfilled lacunae in the Treaties clarifying uncertain legal terms, enlarging the scope of the EU law. The driving forces behind this creativity were the effet utile of the Community (Union) law (construction of a genuine legal order), contribution to the constitutionalization of Community legal regime (especially the protection of fundamental rights) and building and maintaining the common (internal) market.

It is convincing that in the large majority of the cases the CJEU fulfils the roles assigned to it by the founding treaties of the European Union without any excess, but there are decisions which may be characterized as activist, be they necessary or useful for the proper functioning of the European legal system, and there are decisions (refusing or avoiding to decide) which may be qualified as manifestation of judicial passivism.

Judicial passivism is defined in a narrow sense of the term, the court clearly refuses or avoids to decide the case before it or does not answer the question legitimately referred to it, in the jurisprudence of the CJEU when it systematically waits for the withdrawal of the action, when it exceeds the reasonable time of the proceedings, does not answer the question raised in the preliminary ruling procedure by the national court. The inadmissibility of the questions referred by the national courts may be perceived as passivism when the qualification of 'not a court or tribunal' for the Article 267 TFEU is questionable, when the scope of the EU Charter of Fundamental Rights is defined too narrowly. Cases may arise - at least in theory - in which the Court, while it would be in a position to act, defers the question to the EU or the Member State's legislator or to the national judge to decide, the qualification of the act under scrutiny in annulment proceedings as 'not an act for the Article 263 TFEU' is not entirely convincing. The label of 'judicial passivism in a broad sense of the term' is used when the Court sticks to its position in a questionable manner (conservatism as passivism), steps back from its earlier position, narrowing the scope of EU law expressly or implicitly overruling its former decision or it introduces new conditions with the same result (retreat).

Disturbing extra-legal phenomena, like extra-EU and intra-EU migration flows, deep financial crises in the Euro-zone led the Court to a 'reasonable' or rather, a passivist approach.

Analyzing the Court's case-law in the last two years, it has been demonstrated that the Court systematically opposed the Member States, the Commission and the parties in the main proceedings, arguing in favour of inadmissibility of referrals for preliminary questions - the Court avoided, in a large number of cases, the temptation of judicial passivism. On the other hand, the Court's increased rigour in the preliminary ruling procedures submitted by Wahl and Prete is detectable in the past two years. The Court took a less benevolent approach towards the qualification of 'court or tribunal' of the referring body; the questions proved to be 'hypothetical' more often than before and more importantly the lack of sufficient information regarding the factual and regulatory context ended up more easily with inadmissibility. The reason behind this new approach is a kind of self defence against the overburden of the case-law, maintaining the high quality of management of justice. 
The driving forces behind the passivism of the Courts of the European Union are the 'reasonableness' of the judiciary in time of crisis of the European integration, self-defence against the overburden of the case-law and the unnecessary pressure from the public in order to maintain the health of the management of justice and a certain 'path-dependence' as far as the traditional theoretical foundations of European integration are concerned.

\section{OPEN ACCESS}

This is an open-access article distributed under the terms of the Creative Commons Attribution 4.0 International License (https://creativecommons.org/licenses/by/4.0), which permits unrestricted use, distribution, and reproduction in any medium, provided the original author and source are credited, a link to the CC License is provided, and changes - if any - are indicated. (SID_1)

\section{LITERATURE}

Arnull, Anthony, 'Private applicants and the action for annulment under A 173 of the EC Treaty' (1995) 32 CMLRev 7-49.

Arnull, Anthony 'Judicial activism and the European Court of Justice: how should academics respond?' in Dawson, Mark, de Witte, Bruno, Muir, Elise (eds), Judicial Activism at the European Court of Justice (Edward Elgar 2013) 211-32.

Azoulai, Loïc, 'The European Court of Justice and the duty to respect sensitive national interests' in Dawson, Mark, de Witte, Bruno, Muir, Elise (eds), Judicial Activism at the European Court of Justice (Edward Elgar 2013) 167-87.

Beck, Gunnar, The Legal Reasoning of the Court of Justice of the EU (Hart 2012).

Bobek, Michal, The European Court of Justice of the European Union (College of Europe 2014).

Chaltiel, Florence, 'Le pacte de stabilité, entre exigences juridiques et pragmatisme politique A propos de l'arrêt du 13 juillet 2004' (2004) Revue du marché commun et de l'Union européenne, 643-55.

Chiti, Eduardo and Teixeira, Pedro Gustavo, 'The constitutional implications of the European responses to the financial and public debt crisis.' (2013) CMLRev 50 683-708.

Convay, Gerard, 'The Limits of Legal Reasoning and the European Court of Justice'(CUP 2012).

Coutron, Laurent, 'L'arrêt Schul: une occasion manquée de revisiter la jurisprudence Foto-Frost?' (2007) Revue trimestrielle de droit européen 491-511.

Dawson, Mark, de Witte, Bruno and Muir, Elise (eds), Judicial Activism at the European Court of Justice (Edward Elgar 2013).

Editorial, A 'Realist Court?' (2017) 42 ELR 311-12.

European Court of Justice, (2018) Annual Report 2018 Judicial Activity.

Fagioli, Carlotta, 'Horizontal Direct Effect of Directives: the Definitive Cure to the 'Infant Disease' of Community Law?' http://www.academia.edu/2531441/Horizontal_direct_effect_of_directives_ the_definitive_cure_to_the_infant_disease_of_Community_Law accessed $1 \overline{2}$ January 2019 .

Goldner Lang, Iris, 'Towards 'Judicial Passivism' in EU Migration and Asylum law?' (Annual Odysseus Conference, February 2018) 76-85.

Gimbergen, Ramona, 'How Boundaries Have Shifted On Jurisdiction and Admissibility in the Preliminary Ruling Procedure' (2015) 2 Review of European Administrative Law (2015) 39-70.

Herzog, Roman, Gerken, Lüder, 'Stop the European Court of Justice' (2008) EUobserver https:// euobserver.com/opinion/26714 accessed 7 November 2019.

Holdgaard, Rass, Elkan, Daniella, and Krohn Schaldemose, Gustav, From cooperation to collision: the ECJ's Ajos ruling and the Danish supreme court's refusal to comply. (2018) 55 CMLRev $17-54$.

Huyue Zhang, Angela, 'The Faceless Court' (2016) 1 University of Pennsylvania Journal of International Law 71-135.

Iliopoulou-Penot, Anastasia, 'Deconstructing the former edifice of Union citizenship? The Alimanovic judgment Case C-67/14, Jobcenter Berlin Neukölln v. Nazifa Alimanovic and Others Judgment of 
the Court (Grand Chamber) of 15 September 2015 ECLI:EU:C:2015:597' (2016) 53 CMLRev 1007-36.

Jacob, Marc, Precedents and Case-based Reasoning in the European Court of Justice (CUP 2014).

Kaleda, Saulius,Lukas, 'Immediate Effect of Community Law in the New Member States. Is there a Place for a Consistent Doctrine?' (2004) 1 European Law Journal 102-22.

Kaupa, Clemens, 'Maybe not activist enough? On the Court's alleged neoliberal bias in its recent labor cases' in Dawson, Mark, de Witte, Bruno, Muir, Elise (eds), Judicial Activism at the European Court of Justice (Edward Elgar 2013) 56-75.

Kenney, Sally J., 'Beyond Principals and Agents Seeing Courts as Organizations by Comparing Référendaires at the European Court of Justice and Law Clerks at the U.S. Supreme Court' (2000) 33 Comparative Political Studies 593-624.

Korkea-aho, Emilia, Adjudicating New Governance Deliberative Democracy in the European Union (Routledge 2015).

Kostakopoulou, Dora, 'What Fractures Political Unions? Failed Federations, Brexit and the Importance of Political Commitment' (2017) 42 ELRev 339-52.

Krommendijk, Jasper, 'The highest Dutch courts and the preliminary ruling procedure: Critically obedient interlocutors of the Court of Justice' (2019) 25 European Law Journal, 394-415.

Lang, Richard, 'Comment on Érsekcsanádi Mezőgazdasági' (2015) ELRev 89-99.

Láncos, Petra Lea, 'Case Note: Ynos - Intertemporality and Jurisdictional Jurisprudence of the ECJ' (2007) 48 Acta Juridica Hungarica 87-97.

Lecourt, Robert, Europe des juges (Bruylant 1976).

Lenaerts, Koen, 'Unity of European Law and Overload of the ECJ - the System of Preliminary Rulings Revisited' in The Global Community Yearbook of International Law and Jurisprudence (OUP 2005) 211-39.

Lenaerts, Koen, Maselis, Ignace, Gutman, Kathleen, EU Procedural Law (OUP 2014).

Möschel, Mathias, 'Race discrimination and access to the European Court of Justice: Belov' (2013) 50 CMLRev 1433-50.

Maduro, Miguel Poiares, We, the Court The European Court of Justice and the European Economic Constitution. A Critical Reading of Article 30 of the EC Treaty (Hart 1998).

Maher, Imelda,' Economic policy coordination and the European Court: excessive deficits and ECOFIN discretion' (2004) 29 ELRev 831-41.

Martínez, Martín, 'New Developments on the Free Movement of Persons in the European Union in a Time of Crisis - Eroding European Citizenship?' in Schmidt, Jessica, Esplugues, Carlos, García, Rafael Arenas (eds), EU Law after the Financial Crisis (Intersentia 2016) 263-76.

Markakis, Menelaos and Dermine, Paul, 'Bailouts, the status of Memoranda of Understanding, and the scope of application of the EU Charter: Florescu' (2018) 55 CMLRev 643-72.

Nic Shuibne, Niamh, Maci, Marsela, 'Proving public interest: the growing impact of evidence in free movement case law' (2013) 50 CMLRev 965-1006.

Nic Shuibne, Niamh, 'Limits Rising, Duties Ascending: The Changing Legal Shape of Union Citizenship'(2015) 52 CMLRev 889-938.

Pech, Laurent, 'Between judicial minimalism and avoidance: The Court of Justice's sidestepping of fundamental constitutional issues in Römer and Dominguez.' (2012) 49 CMLRev 1841-80.

Picod, Fabrice, Van Drooghenbroeck, Sébastien, Rizcallah, Cecilia (eds), Charte des droits fondamentaux de l'Union européenne Commentaire article par article (Bruylant, 2018).

Ragolle, Filip, 'Access to justice, for private applicants in the Community legal order: recent (r) evolutions' (2003) 28 ELRev 90-101.

Rasmussen, Hjalte, 'Why is Article 173 EC interpreted against private plaintiffs?' (1980) 5 ELRev $112-27$.

Rasmussen, Hjalte, On Law and Policy in the European Court of Justice. A Comparative Study in Judicial Policy-Making (Martinus Nijhoff 1986).

Sarmiento, Daniel, 'Half a case at a time: Dealing with judicial minimalism at the European Court of Justice' in Claes, Monica, de Visser, Maartje, Popelier, Patricia, Van de Heyning Catherine (eds), Constitutional Conversations in Europe (Intersentia 2012) 13-40.

Susanne K. Schmidt, Susanne K., 'Who cares about nationality? The path-dependent case law of the ECJ from goods to citizens' (2012) 19 Journal of European Public Policy 8-24. 
Sibony, Anne-Lise, 'La jurisprudence de la Cour au prisme de la science économique' in Mbongo, Pascal et Vauchez, Antoine (eds), Dans la fabrique du droit européen (Bruylant 2009), 171-97.

Pierre Thielbörger, Pierre, 'Judicial Passivism at the European Court of Human Rights' (2012) 3 Maastricht Journal of European and Comparative Law 341-47.

Thym, Daniel, 'The Elusive Limits of Solidarity: Residence Rights of and Social Benefits for Economically Inactive Union Citizens' (2015). 52 CMLRev 17-50.

Thym, Daniel, 'When Union citizens turn into illegal migrants: The Dano case' (2015) 40 ELRev $248-61$.

Tridimas, Takis, ‘The Court of Justice and Judicial Activism' (1996) 21 ELRev 199-210.

Tridimas, Takis, 'Precedent and the Court of Justice A Jurisprudence of Doubt?' in Dickson, Julie and Eleftheriadis, Pavlos (ed), Philosophical Foundations of European Union Law (OUP 2012) 307-30.

Van Malleghem, Pieter-Augustijn and Baeten, Niels, 'Before the law stands a gatekeeper - Or, what is a 'regulatory act' in Article 263 (4) TFEU? Inuit Tapiriit Kanatami Case C-583/11 P, Inuit Tapiriit Kanatami and Others v. Parliament and Council, Judgment of the Court of Justice (Grand Chamber) of 3 October 2013 (EU:C:2013:625) (2014) 51 CMLRev 1187-216.

Varju, Márton, 'The Right to Effective Judicial Protection in the System of Judicial Review in the European Community' (2003) 44 Acta Juridica Hungarica 99-127.

Varju, Márton, 'The crisis, judicial power and EU law' in Zoltán Szente, Fruzsina Gárdos-Orosz (eds), New Challenges to Constitutional Adjudication in Europe: A Comparative Perspective (Routledge 2018) 281-310.

Várnay, Ernő, ‘Sanctioning Under Article 260 (3) TFEU - Much Ado About Nothing?' (2017) 23 European Public Law 301-16.

Verschueren, Herwig, 'Preventing "Benefit Tourism" in the EU: A Narrow or Broad Interpretation of the Possibilities Offered by the ECJ in Dano?' (2015) 52 CMLRev 363-390.

Waelbroek, Denis, 'Le droit au recours juridictionnel effectif du particulier trois pas en avant, deux pas en arrière' (2002) 38 Cahiers de Droit Européen, 3-8.

Wahl, Nils and Prete, Luca, 'The gatekeepers of Article 267 TFEU: On jurisdiction and admissibility of references for preliminary rulings' (2018) 50 CMLRev 511-48.

Weiler, Joseph Halevi, Horovitz, 'The Transformation of Europe' (1991) 100 The Yale Law Journal, 2403-83. 